\title{
Petrography of Bethampudi Anorthosites Layered Complex from the Khammam Schist Belt, Telangana, India
}

\section{Thallapalli Brahmaiah1, Chinthala Ravi², Kandukuri Sai Krishna3, Gugulothu Papanna ${ }^{3}$, Katta Satya Sai Prasad1}

${ }^{1}$ Department of Geology, Sri Venkateswara University, Tirupathi, India

${ }^{2}$ University PG College, Kakatiya University, Jangoan, India

${ }^{3}$ Department of Geology, Kakatiya University, Warangal, India

Email: brahmamt@gmail.com

How to cite this paper: Brahmaiah, T., Ravi, C., Krishna, K.S., Papanna, G. and Prasad, K.S.S. (2016) Petrography of Bethampudi Anorthosites Layered Complex from the Khammam Schist Belt, Telangana, India. Open Journal of Geology, 6, 1434-1456. http://dx.doi.org/10.4236/ojg.2016.611102

Received: October 6, 2016

Accepted: November 21, 2016

Published: November 24, 2016

Copyright $\odot 2016$ by authors and Scientific Research Publishing Inc. This work is licensed under the Creative Commons Attribution International License (CC BY 4.0).

http://creativecommons.org/licenses/by/4.0/

\section{Abstract}

The Bethampudi layered anorthosite complex at the border zone of Archaean supracrustal rocks of Khammam district, Eastern Ghats shows normal stratification predominantly in the form of rhythmic layering and often exhibits of zebra layering. Graded bedding and cumulate structures are also noticed. The rocks of the study area are classified based on petrography into anorthositic rocks, gabbroic rocks and ultramafic rocks and amphibolites. The field relations and major element composition suggest that these anorthosite rocks are of calc-alkaline in nature and petrogenitically related to the gabbroic rocks by the fractional crystallization at $<750^{\circ} \mathrm{C}$.

\section{Keywords}

Bethampudi Layered Anorthosite Complex, Petrographic Classification, Calc Alkaline Nature, Fractional Crystallization of Gabbroic Rocks

\section{(c) (i) Open Access}

\section{Introduction}

Anorthosites of Bethampudi area are coarse grained, plagioclase-high rich ( $>70$ vol. \% of rock-modal composition) cumulates of plutonic igneous rocks that have variation of basaltic magmas of mantle origin [1] [2]. The occurrences of anorthosites are volumetrically minor and spread the entire geological column, but more constrained to Precambrian terrains. Majority of anorthosites were mainly confined to high grade granulite-gneiss belts and low grade granite-greenstone belts of the Precambrian terrains [3] [4] [5] [6] [7]. Minor anorthosite components in the younger mafic layered intrusions 
and in basaltic volcanic provinces of the Phanerozoic to recent periods are uncommon. The world-known anorthositic occurrences are broadly classified into six major and distinct groups on the basis of their form, internal structure and texture, nature and composition of plagioclase feldspar [1] [8] [9]:1) the Archaean metamorphosed layered complexes (Fiskenaesset type); 2) the Proterozoic massif anorthosites (Adirondacktype); 3) layered mafic intrusions (Bushveld-type); 4) Anorthosites in oceanic setting (in ophiolites); 5) Anorthosite inclusions in other igneous rocks and 6) Extra-terrestastrial anorthosites (lunar-type).

Archaean anorthosites comprise layered components of few or all the following: anorthosite, leuco-gabbro, gabbro, mela-gabbro and ultramafic rocks (including chromitites). They contain textures and structures similar to those of younger layered basic intrusions, but are generally distinguished by the abundance of anorthositic rocks over mafic (gabbros) and ultramafic rocks, the equidimensional high calcic plagioclase with a high anorthite content at $\mathrm{An}_{80-85}$ and affected by different degrees of metamorphism and deformation [10] [11]. They also differ in overall structure and composition from Proterozoic massif-type anorthosites which commonly form large steep-sided plutons and are characterized by tabular crystals of intermediate plagioclase $\left(\mathrm{An}_{40-60}\right)$ composition [7] [10] [12] [13].

Excellent evaluations on the Archaean metamorphosed layered complexes by [3] [4] [10] [14] [15] have provided descriptions and illustrations of the archean anorthosite complexes and these are variously interpreted as: 1) metamorphosed equivalents of mafic layered intrusions such as Bushveld [16] [17]; 2) tectonic slices of lower crust [18]; 3) fragments of the Earth's putative primordial anorthositic crust [19]; 4) segments of ancient oceanic crust [20]; 5) early cumulates from the precursor magmas to the voluminous tonalite gneisses, which now enclose the complexes [21];6) subducted oceanic lithosphere at cordilleran type continental margins [3] [22]; 7) cumulates complement to greenstone belt basaltic volcanism [4] [10] [23] [24] [25].

The Bethampudi Anorthositie Complex is in northern portion to Chimalpahad Layered Complex (CLC), Telangana State, and the largest, deformed and metamorphosed Archaean anorthosite complex in Khammam Schist belt of southern Peninsular India [1] [11] [15] [26]. The occurrence of calc plagioclase (An80-85) as cumulus, and hornblende as the chief mafic mineral, is a spectacular igneous deformation and metamorphosed one [11] [27] [28]. Bulk chemical composition [28] of the CLC is the hall-mark of the Archaean metamorphosed layered anorthosite complexes. The petrological distinctions of the BAC are comparable to: 1) Fiskaenaesset complex of southwest Greenland [3] [10] [14] [29]; 2) Sittampundi complex of south India [30] [31] [32]; 3) Shawmere complex of Ontario, Canada [24]; 4) Messina complex of South Africa [23] [33] and 5) Bad Vermilion Lake complex of Ontario, Canada [25].

The present paper discusses on petrography and geochemical interpretations of major elements of rocks from Bethampudi Anorthosite complex (BAC) of Khammam district, Telangana State. Based on geochemical studies, a genetic link between the rocks from BAC and associated mafic granulites and has been proposed. A possible parental 
magma was suggested along with geodynamic setting of the BAC and its associated mafic and felsic volcanic rocks in Khammam schist belt.

\section{Geological Setting}

The Bethampudi Anorthosite complex extending $>100$ sq. km included in the survey of India Toposheet Nos. $65 \mathrm{C} / 7$ and $65 \mathrm{C} / 10$; and boundary by latitudes $17^{\circ} 30^{\prime}$ and $17^{\circ} 35^{\prime} \mathrm{N}$, and longitudes $80^{\circ} 25^{\prime}$ and $80^{\circ} 35^{\prime} \mathrm{E}$ (Figure 1 ). The BAC is syntectonically emplaced as a "sill-like" intrusive body trending NE-SW direction within the Khammam Schist Belt (KSB). Smaller outcrops of the BAC that are spatially separated from the main body by prominent shear zones, occur as tectonically dismembered and deformed sheets and lenses in the southern, northern and western parts of the complex. Further, the complex is intruded by younger intrusive dyke, quartz veins and pegmatites. The rocks of BAC have been affected by three phases of ductile-brittle deformation and metamorphism under upper amphibolite to lower granulite facies [11]; hence, clear-cut stratigraphic sequence of the magmatic disposition in the BAC could not be established; and the magmatic structures exhibits variably witnessed complex-folding and fracturing which was overprinted on the primary igneous layering during transpressive tectonism [11].

The several members of the complex are classified into three lithological units based on their mafic mineral content, following the one adopted by [14]: 1) anorthositic rocks; 2) gabbroic rocks and 3) ultramafic rocks. Anorthositic rocks include minor anorthosites ( $0 \%-10 \%$ of mafic minerals), predominant gabbroic anorthosites (10\% $20 \%$ of mafic minerals) and anorthositic gabbros (20\% - 35\% of mafic minerals). Anorthositic rocks constitute the bulk (>95\%) of the BAC, and can be petrographically divided into two varieties: 1) garnet-bearing and 2) garnet-free anorthositic rocks. The garnet-bearing anorthositic rocks are comparatively less abundant than the garnet-free varieties; the former varieties generally confined to shear zones in the BAC. Garnet-

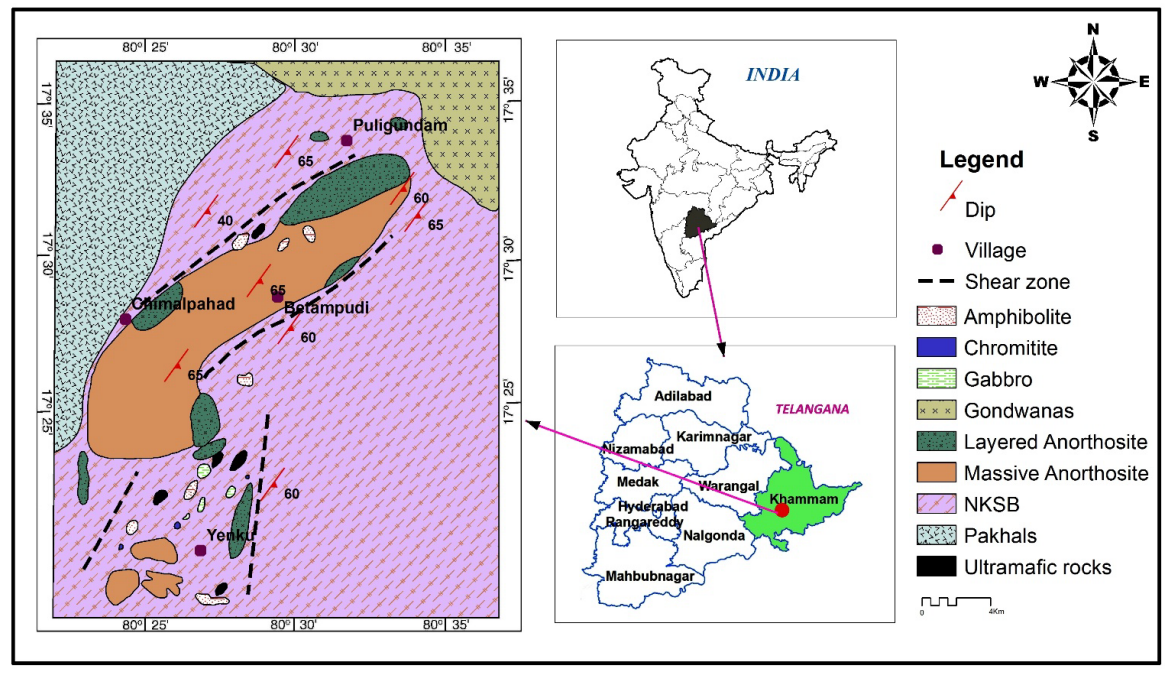

Figure 1. Location \& geology map of Bethampudi layered complex. 
free varieties are widespread over the hill ranges of the area. Layering with cumulus texture is the prominent primary feature of the anorthositic rocks and is extremely well preserved in these rocks at different localities of the marginal zone of the BAC. Gabbroic rocks (35\% - 65\% of mafic minerals) are the distinct mafic rock units of the BAC. They are sparsely distributed and have limited areal extent in the complex. They occur as younger concordant bands and lenses in the anorthositic rocks. Ultramafic rocks ( $>65 \%$ of mafic minerals) are seldom occur in the BAC. They occur as lenses and minor bands in the complex.

\subsection{Amphibolites}

Are the significant mafic rocks and associated with the rocks of the BAC and the tonalitic gneisses of the Khammam schist belt, Telangana State. The amphibolites are of texturally two types: 1) Banded and schistose type occurring as intercalated bands with tonalitic gneisses exposed in the plane country, and 2) massive type which occurs as sills and dikes of variable dimensions (few meters to hundreds of meters in length), lenses (few meters to tens of meters in diameter) and tectonic slices, rafts and flows (few meters to hundreds of meters in length) in and around BAC and in plane country of the KSB. They locally exhibit grain size variation from fine grained massive type to coarse grained schistose type.

\subsection{Mafic Granulites}

Look similar gabbroic rocks in the field, but they vary from the latter by their typical characteristic of mineral assemblages; granoblastic texture, and nonappearance of cumulate characteristics. They arise as lenses, dykes and small mounds in the KSB and are generally located at the marginal portion of the BAC, Similar to those in high pressure retrograde granulites of Ungava orogen, Canada [34]. Therefore, the mafic granulites around the BAC may be considered as high pressure retrogressive granulite facies metamorphic products of fine grained gabbros [11].

The BAC includes anorthosites, gabbroic anorthosites and anorthositic gabbros, and subordinate gabbros and pyroxenites. Spectacular phase layering of different styles and scales is observed, particularly in low-strain zones. The magmatic structures of AC include rhythmic grading, cyclic (cryptic) layers, zebra banding, cross bedding, trough structures, and cumulate textures [11] [35]. The cyclic layering is made up of different proportions of felsic (plagioclase) and mafic (hornblende + clinopyroxene) phases (Figure 2(a) and Figure 2(b)), the felsic and mafic layers have either gradational or sharp contacts. In general, the layering is very similar to that in the Fiskenæsset Complex, West Greenland [10] [14] [29] [36].

The BAC is a polydeformed igneous body with three events of deformation. Ductile-brittle deformation (D1, D2 and D3) is recorded in the rocks of the Bethampudi layered complex during and after emplacement. The first deformation D1 is represented by strong vertical/sub-vertical planer foliation (S1) (Figure 2(c)), and vertical (or horizontal) stretching minerals lineation (L1) in the rocks of the Bethampudi 


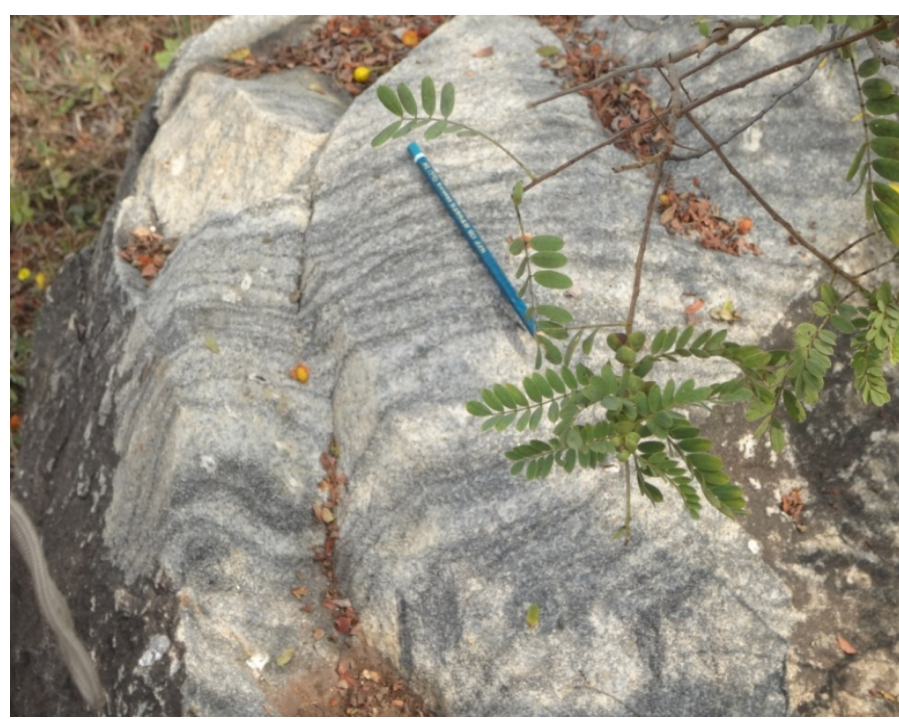

(a)

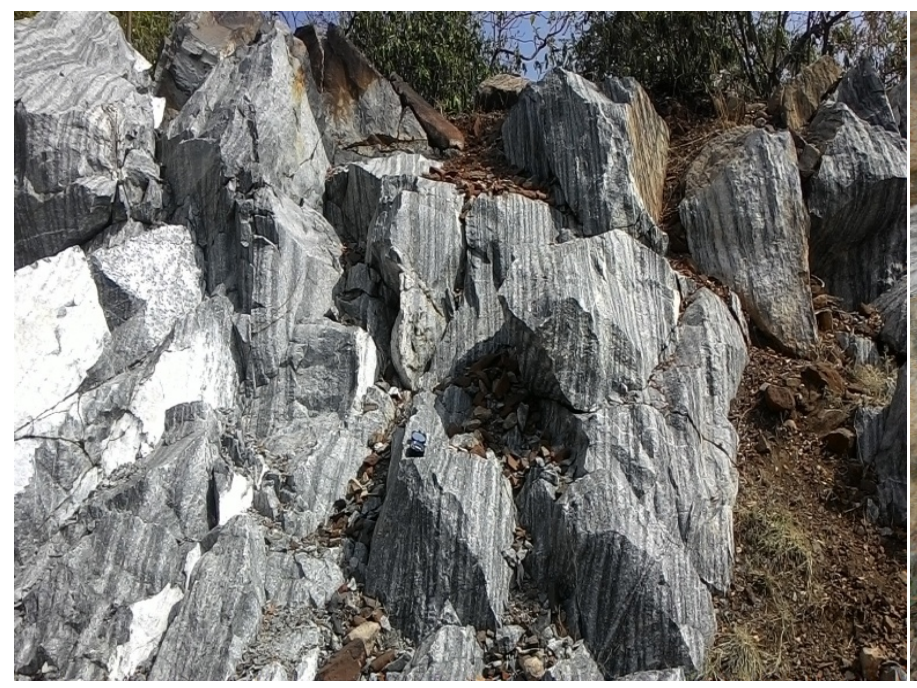

(c)

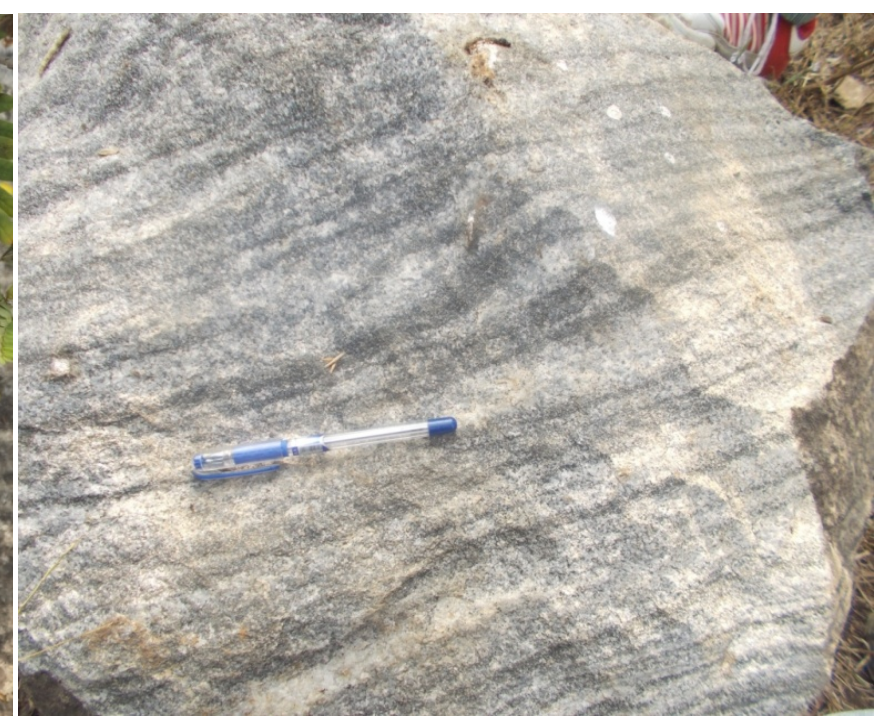

(b)

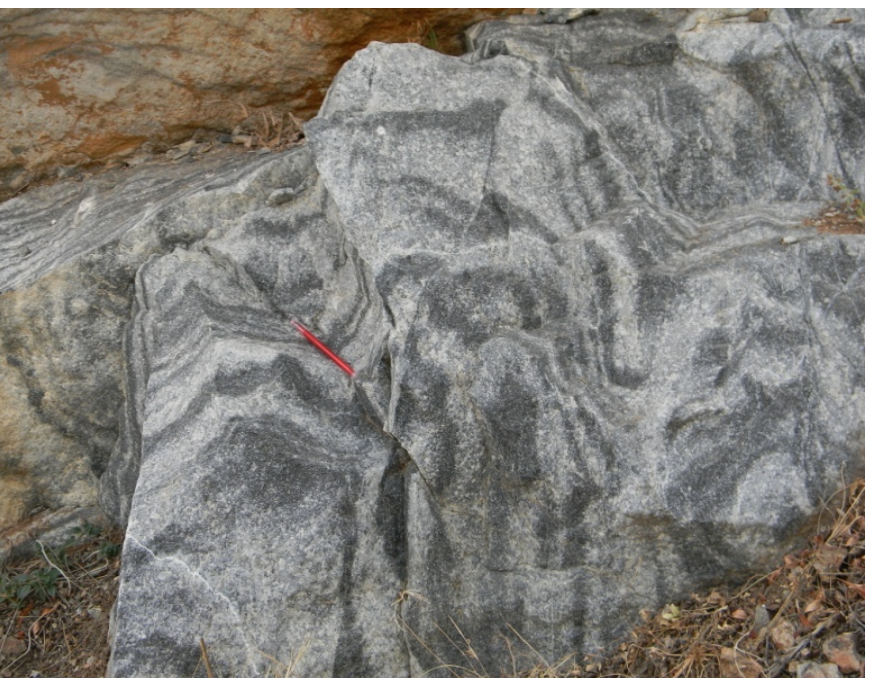

(d)

Figure 2. (a): Rhythmic layering in the layered leucogabbro; (b): Mineral-graded layering in the layered leucogabbro; (c): The deformation is represented by strong vertical/sub-vertical planer foliation and (d): Folding in anorthosites (scale: $13 \mathrm{~cm}$ pen).

layered complex. The stretching lineation (L1) is defined by the preferred orientation of the: 1) aggregate crystals of amphibole and 2) stretched bands of amphibole-rich layers in the layered leucogabbros. The structural features of the D1 deformation are widespread in the rocks of the Bethampudi layered complex and are inferred to have developed by NE-SE coaxial component of shortening. D2 ductile deformation is represented by the folding event of the complex (Figure 2(d)).

\section{Petrography}

\subsection{Mineralogy}

The anorthositic rocks from the BAC are mainly mixtures of two minerals: plagioclase 
and hornblende. However, both ortho- and clino-pyroxenes become more dominant in mafic and ultramafic rocks of the BAC (Table 1). Garnet, zoisite, clino-zoisite, epidote and scapolite form minor minerals, while quartz and calcite form accessory minerals. Table 1 indicates the volume percent of plagioclase which gradually decreases with increasing volume percent of hornblende from pure anorthosite to leuco gabbroic members (gabbroic anorthosite to anorthositic gabro) of anorthositic rocks [1] [5] [6] [7]. It indicates an inverse relationship between volume percent of plagioclase verses hornblende from these anorthositic rocks. Plagioclase inclusions in hornblende and viceversa from anorthositic rocks indicate that they are in mutual coexisting primary phases.

Plagioclase, in general is coarse grained $(>1 \mathrm{~mm})$ and subhedral to anhedral and grain size decreases (greater than $1 \mathrm{~mm}$ to less than $1 \mathrm{~mm}$ ) with decreasing modal content (98 to 40 volume percent) from anorthositic-to gabbroic-rocks. The plagioclase occurs in different textural forms in the rocks of BAC due to subsolidus reaction process and subsequent deformation and metamorphism, as: 1) big strained cumulus grains entrapped in post cumulus matrix of hornblende/pyroxene/garnet; 2) small grains of strain-free recrystallized polygons and 3) very small anhedral inclusions in hornblende and in porphyroblastic (sieved) garnet. Plagioclase commonly exhibits twinning on the albite and pericline laws but untwined plagioclase is not rare in the rocks of the BAC. Bent twin lamellae and saw-tooth lamellae with feeble to strong zoning are frequently noticed in plagioclases from the deformed Anorthositic and gabbroic rocks (Figure 3(a) \& Figure 3(b)). It is occasionally replaced by scapolite, and zoisite/cli-no-zoisite; and is the sole reactant felsic phase for the growth of garnet porphyroblasts and garent coronas.

Hornblende is the main mafic mineral of the rocks in the BAC. It is fine grained in anorthosites, but its size increases with increasing modal content in the anorthositic rocks. Hornblende from gabbroic and ultramafic rocks is different from that of anorthositic rocks by its distinct colour and texture. Hornblende occurs as: 1) independent discrete grains; 2) coronas over pyroxene/garnet and 3) small anhedral inclusions and needles in coarse cumulus grains of plagioclases (Figure $3(c)$ ) and is similar to that of the Fiskenaesset complex [14]. Inclusions of the hornblende are not uncommon in ortho- and clino-pyroxenes and garnet porphyroblasts. Discrete hornblende is dark green in colour, displaying strong pleochroism, with pleochroic scheme of pale yellowish green, green and bluish green. Coronal and inclusion hornblendes are light green in colour with feeble pleochroism. All the hornblendes in the rocks of the BAC may be considered as metamorphic products of pyroxenes and precursor hornblende [27] [37].

Pyroxenes are dominant mafic minerals in gabbroic and ultramafic rocks. Orthopyroxene is totally absent and clinopyroxene is a minor mineral (it occurs as small anhedral segregates mantled by composite coronas of hornblende, quartz and garnet) in the anorthosites (Figure 3(d)). Clinopyroxene dominates ortho-pyroxene in the two-pyroxene gabbroic rocks. Both ortho- and clino-pyroxenes are frequently rimmed by coronal garnet and coronal hornblende in the gabbroic rocks. Orthopyroxene occurs as: 1) intercumulus mafic silicate phase along with clinopyroxene/hornblende between the 


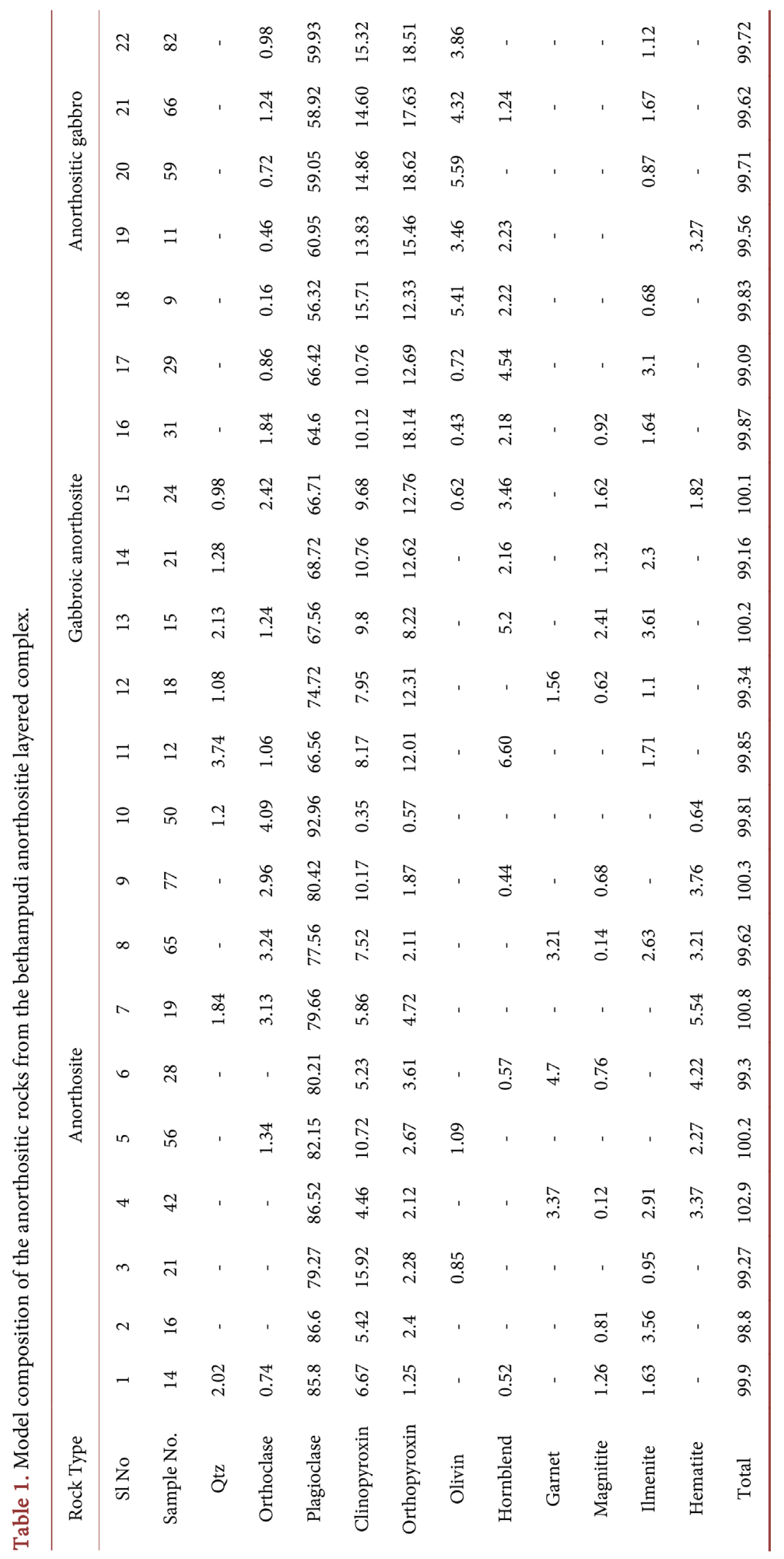




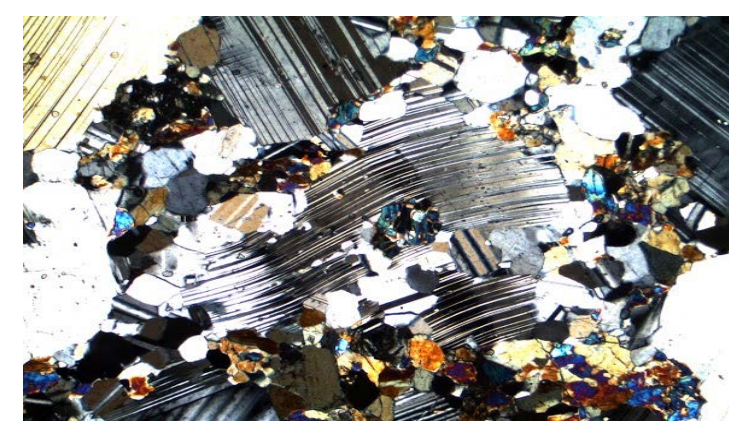

(a)

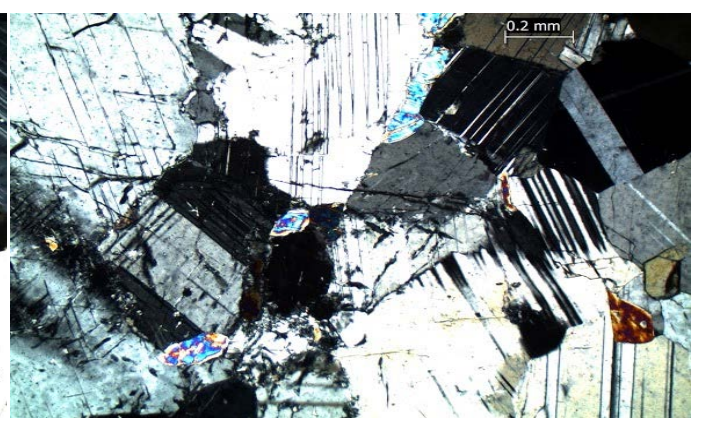

(b)

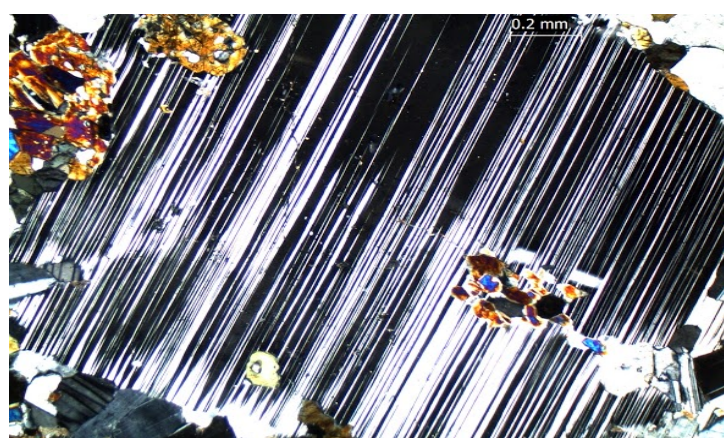

(c)

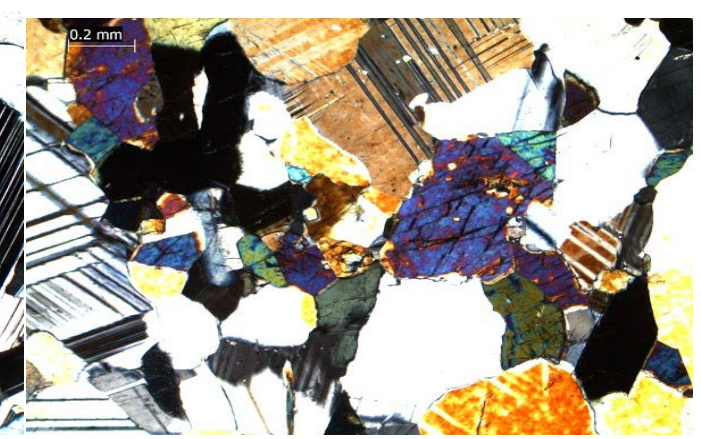

(d)

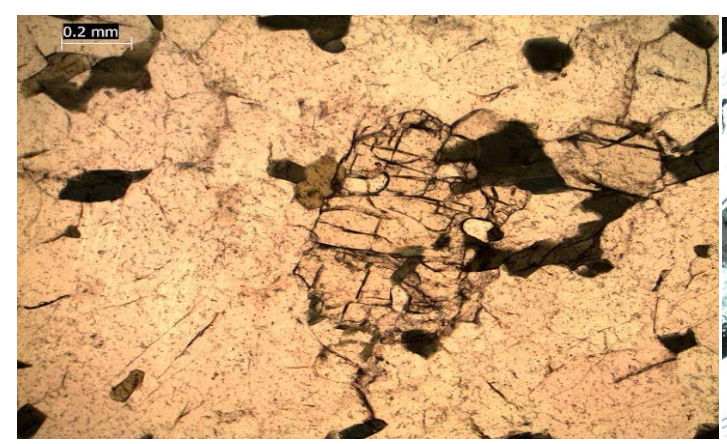

(e)

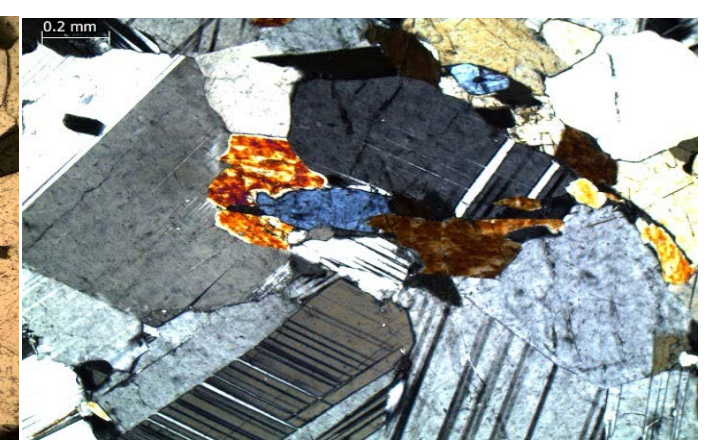

(f)

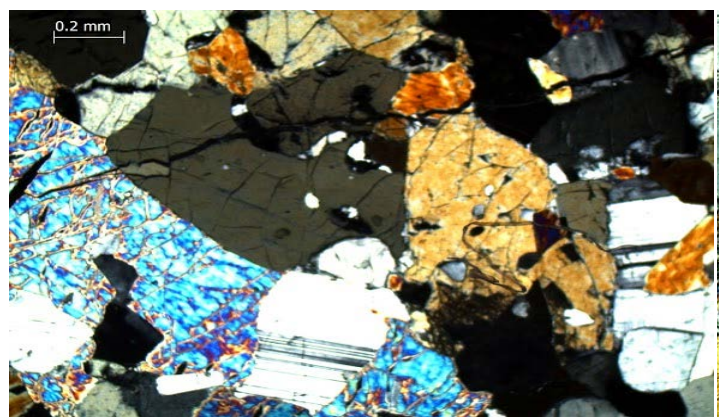

(g)

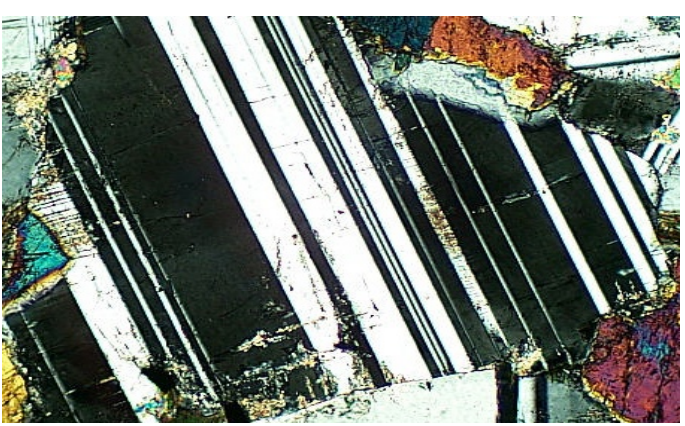

(h)

Figure 3. (a): Bent twin lamellae and saw-tooth lamellae in plagioclase from the deformed anorthositic gabbro; (b): Stained cumulus grains of plagioclase entrapped in post cumulus matrix of hornblende and pyroxene; (c): Small anhedral grains of hornblende in cumulus grains of plagioclase; (d): Sub-hderal clinopyroxene grains mantiled by hornblende and garnet in anorthosites; (e): Porphyroblastic garnet; (f): Pleagioclase is primary cumulus and hornblende and pyroxene are intercumulus in anorthosites; (g): Garnet corona at the interface between plagioclase, orthopyroxene and hornblende and (h): Development of epidote minerals on plagioclase. 
cumulus plagioclase grains and 2) recrystallized fine graines with xenomorphic to anhedral aggregates in the gabbroic rocks. Clinopyroxene occurs as: 1) deformed porphyroclasts; 2) recrystallized strain-free aggregates; 3) post-cumulus mafic silicate phases as interstial fine grained matrix between cumulus plagioclase grains and 4) inclusions in garnet porphyroblasts. It is light green colour, medium to coarse grained and subhedral to anhedral in form. Pyroxenes from ultramafics are frequently display exsolution lamellae of ilmenite hornblende. They have been generally altered to talc, tremolite, actinolite, anthophyllite and gedrite. Pseudomorphs of hornblendes and actinolites on clino-pyroxenes are rarely observed in the ultramafic rocks.

Epidote (zoisite, clino-zoisite and epidote) is occasionally found in minor quantities. They occur as tabular and euhedral crystals, and as small rounded grains. They are totally absent in gabbroic and ultramafic rocks. Scapolite is a common accessory mineral found all the rocks of the BAC. It occurs as altered product of plagioclase. Calcite is common in the anorthositic rocks and occurs as veins with radiating and tabular crystals.

Garnet is found in variable proportions in all the rocks of the BAC. It occurs in two forms: 1) coronal and 2) porphyroblastic types. The coronal garnet has width from 0.1 to $0.5 \mathrm{~mm}$, while the porphyroblastic type with sieved micro-structures is very coarse (>2 mm). Garnet frequently exhibits euhedral crystals of chains/necklaces porphyroblasts, poiklioblasts and anhedral sieved grains (Figure 3(e)).

Amphibolites are mineralogically sub-divided into 1) clino-pyroxene bearing amphibolites; 2) sphene-bearing amphibolites; 3) garnet-bearing amphibolites mainly composed of hornblende and plagioclase as major minerals (Table 1). Garnet, epidote and scapolite occur as minor minerals. Clinopyroxene is considerably higher proportion in some amphibolites, but the orthopyroxene is completely absent in all amphibolites. Biotite, sphene, quartz and Fe-Ti oxides form the accessories in these rocks.

Mafic granulites have distinct mineralogy and textures, when compared to rocks from the BAC. Pyroxenes are dominant over amphiboles in these mafic granulites. Clinopyroxenes are greater in proportions than orthopyroxenes and this feature is different from that of gabbroic rocks of the BAC. Absence of epidote group minerals and presence of biotite and sphene from mafic granulites are distinct mineralogic variations from those of the rocks from the BAC. Scapolite, and quartz form as accessories in the mafic granulites (Table 1).

\subsection{Textures}

The rocks in BAC are, in general, coarse grained and granular in form. The anorthositic rocks occasionally exhibit plaigoclase-rich felsic layers and hornblende (garnet/clinopyroxene)-rich mafic layers, and they also display parallel alignment of lenticular hornblende and randomly distributed garnet porphyroblasts.

The rocks of the BAC exhibit a variety of textural features ranging from relict magmatic to metamorphic (and deformation) fabric. The textures of the BAC are broadly classified into: 1) relict igneous cumulus textures; 2) metamorphic recrystallized equili- 
brium (and rarely disequilibrium) textures; 3) replacement textures and 4) deformation fabrics.

Cumulus textures (Figure 3(f)) are common in anorthositic, gabbroic and ultramafic rocks. In anorthositic and gabbroic rocks plagioclase is a primary cumulus phase and mafic silicates (hornblende and pyroxenes) are inter cumulus phases. However, these mafic silicates form the as cumulus phases in the ultramafic rocks.

The rocks of the complex exhibit, by and large, metamorphic equilibrium textures. Equant polygonal grains and smooth planar boundaries with triple junctions indicate solid-state recrystallization (due to grain-boundary migration during plastic deformation at higher temperatures); grain size reduction and sub-grain rotation took place in the rocks in the high strain zones by dynamic recrystallization at lower temperatures [38].

Metamorphic disequilibrium textures are locally developed due to diffusion-controlled and interface-controlled metamorphic reactions. Thin zone of white plagioclase moat around garnet porphyroblasts and rapid growth of sieved garnets with "inclusions" of plagioclase, hornblende, pyroxene and Fe-Ti oxide minerals represent diffusion-controlled metamorphic reaction textures. While garnet coronas at the interface between plagioclase and clinopyroxene/orthopyroxene/Fe-Ti oxide minerals, and composite coronas of garnet, hornblende and quartz between plagioclase and clinopyroxene (Figure 3(g)) represent interface-controlled metamorphic reaction textures [39].

Retrogressive replacement textures are were observed in the rocks and appears to be an account of as above: 1) simple structural transformation due to decline of temperature; and 2) chemical alteration due to fluid action. A rare feature of epitaxial overgrowth of hornblende over clinopyroxene is an example of structural transformation. Frequent occurrence of hornblende rims over clinopyroxene/orthopyroxene/garnet/FeTi oxide minerals and the development of scapolite and epidote minerals on plagioclase are the examples of retrogressive alteration by fluid action (Figure $3(\mathrm{~h})$ ).

Many of the textural features observed in the BAC mimic those exhibited by the Fiskenaesset complex [14] [23] [33] [40], Sittampundi complex [30] [31]. However, the typical garnet symplectitic textures are totally absent in BAC, unlike those present in the Sittampundi anorthosite complex [30] [41].

Mafic granulites typically show granoblastic texture with sieved as well as coronal garnets, flakes of biotite, rounded grains of sphene. Some of the mafic granulites exhibit exsolution lamellae of ilmenite in clinopyroxene, and these lamellae occur only in the core portion of clinopyroxene. Relict exsolution lamellae of thin clinopyroxene in orthopyroxene, orthopyroxene in clinopyroxene, and relict sub-ophitic textures are occasionally preserved in some of the mafic granulites. The mineralogic assemblage and textural features of the mafic granulites are distinctly different from those of the gabbroic rocks of the BAC.

Amphibolites commonly exhibit both non-foliated and foliated metamorphic textures. They rarely show microfolding mylonitic and garnet coronal microtextures. Relict magmatic textures like ophitic are rarely observed in some of the amphibolites. 


\section{Geochemistry}

\subsection{Analytical Procedure}

Typically, unaltered and fresh samples, showing the widest possible variation in modal mineralogy, were analyzed for major elements. Cleaned chips were powdered to $\sim 200$ mesh using a steel jaw crusher and a ring mill. The rock powders were analyzed by X-ray fluorescence spectrometry (XRF) using Philips MAGIX PRO-Model $244 \mathrm{O}$ for the major elements. Representative whole rock analyses are presented in Table 2(a) \& Table 2(b).

\subsection{Major Element Geochemistry}

6 Anorthosite rocks, 6 Gabbroic anorthosites, 6 Anorthosites, 2 Gabbroic rocks, 3 ultramafic rocks and 5 Amphibolites Reprehensive samples are analyzed for geochemistry purpose of Bethampudi Anorthosite Complex are presented in Table 2(a). It appears that the bulk chemistry of the anorthosite rocks from the BAC is controlled by the nature, composition and model proportion of cumulus high calcic plagioclase and of inter-cumulus mafic phases as hornblende, clinopyroxene and Fe-Ti oxides. The high plagioclase modes $(>65 \%)$, very high total normative feldspar $(72 \%-92 \%)$ and very high normative plagioclase compositions (An 70-An 95, see Table 2(a)) clearly suggest a very high Cao (11.54 - $16.02 \mathrm{wt} \%)$ and Al2O3 (24.12 - $32.82 \mathrm{wt} \%)$ in their bulk compositions. Other major elements in anorthosite rocks, are small in amount and show large variations in $\mathrm{MgO}(0.11-5.21 \mathrm{wt} \%)$ and in $\mathrm{Fe}_{2} \mathrm{O}_{3}$ (0.25 - $\left.6.74 \mathrm{wt} \%\right)$. Alkalies $\left(\mathrm{Na}_{2} \mathrm{O}+\mathrm{K}_{2} \mathrm{O}\right)$ and $\mathrm{SiO}_{2}$ have restricted range from $1.91 \%-4.7 \%$ and from $44.23-50.23$ $\mathrm{wt} \%$ respectively. These geochemical variations in anorthositic rocks (Table 2(a)) are in a way controlled by the nature, composition and model proportion of intercumulus mafic constituents, particularly hornblende. $\mathrm{TiO}_{2}$ and $\mathrm{P}_{2} \mathrm{O}_{5}$ have far less in amount $<0.6$ wt $\%$ but they show considerable variation from 0.02 to 0.46 wt\% and from 0.010 .67 wt $\%$ respectively.

In the $\mathrm{SiO}_{2}$ vs $\mathrm{Na}_{2} \mathrm{O}+\mathrm{K}_{2} \mathrm{O}$ diagram [46] most of the samples plot in the basalt and basaltic-andesite field (Figure 4). Anorthosite rocks show distinct feldspathic composition and total normative feldspar verses normative plagioclase composition (Figure 5) and also no coherent variation between total normative feldspar, and normative plagioclase composition, instead, there are horizontally spread of points. Anorthositic rocks of the BAC largely have normative olivine and they fall in normative olivine field. However normative quartz is only seen in a few felsic anorthositic rocks (Figure 6). These Anorthosites display a good positive correlation between silica saturation and total normative feldspar. The silica saturation decreases with increasing of mafic components, particularly $\mathrm{MgO}$, at a constant silica percentage from anorthosites through leuco-gabbros (gabbroic anorthosites and anorthositic gabbros). However, silica saturation against normative plagioclase composition (\% An) does not show distinct correlation relationship. These unrelated geochemical parameters are independent to each other and they may be controlled by accumulation of different proportions of cumulus and intercumulus phases in anorthositic and gabbroic rocks of the BAC. Therefore the 
Table 2. (a) Major element chemistry (wt. \%) and norms of the anorthositic rocks from the bethampudi layered complex. (b) Major element chemistry (wt. \%) and norms of the gabbroic, ultramafic and amphibolites associated with Bethampudi layered complex.

(a)

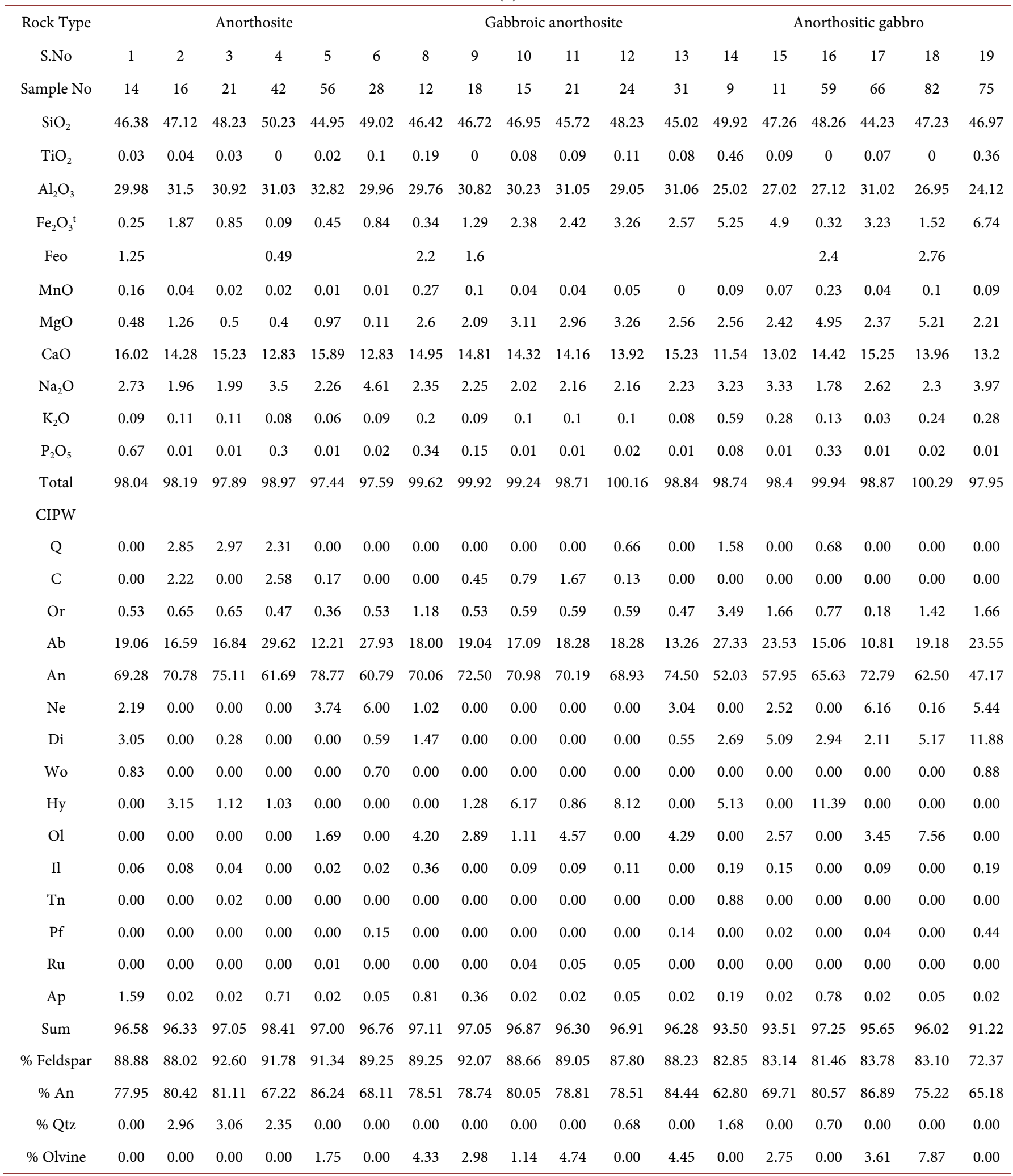


(b)

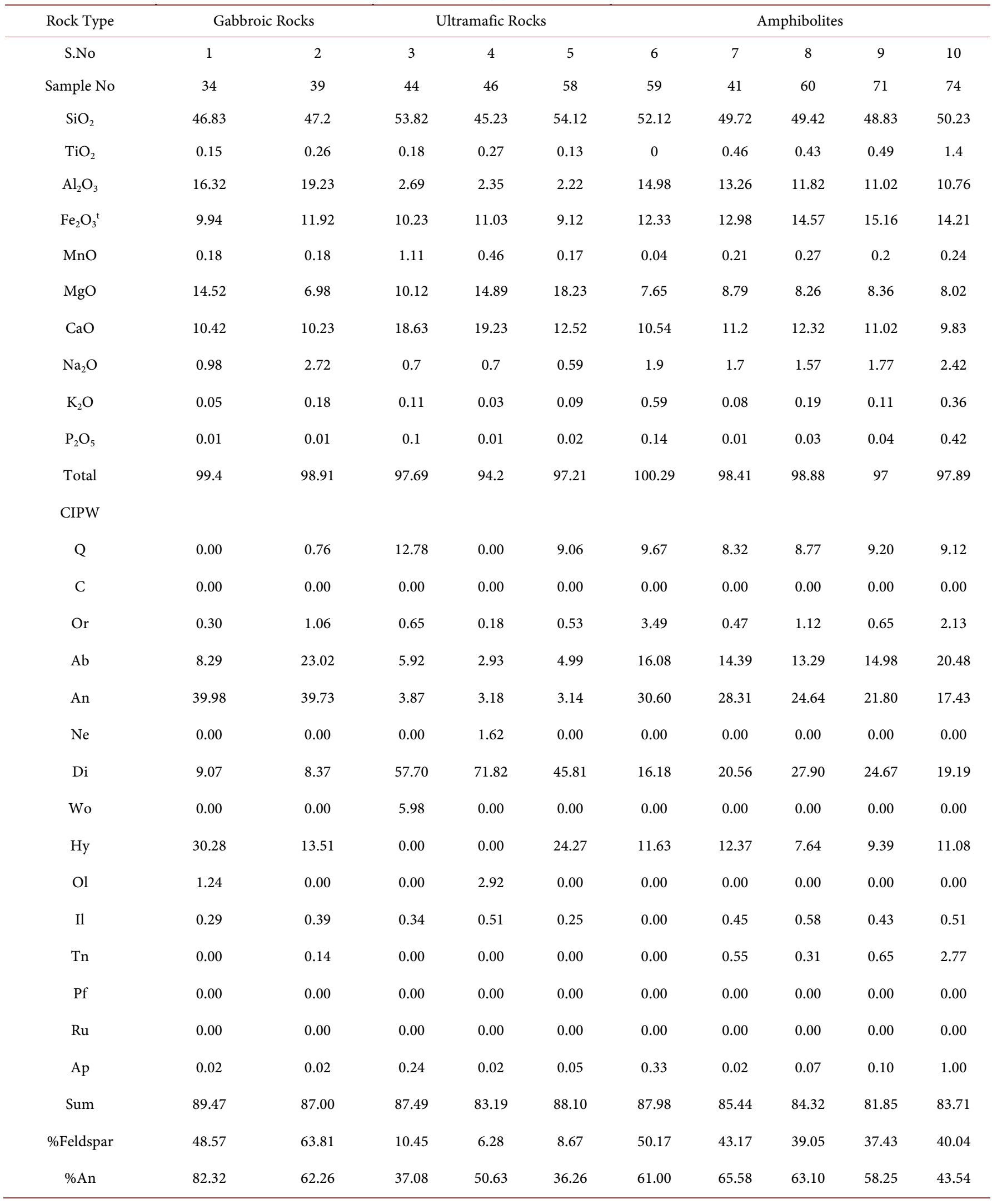




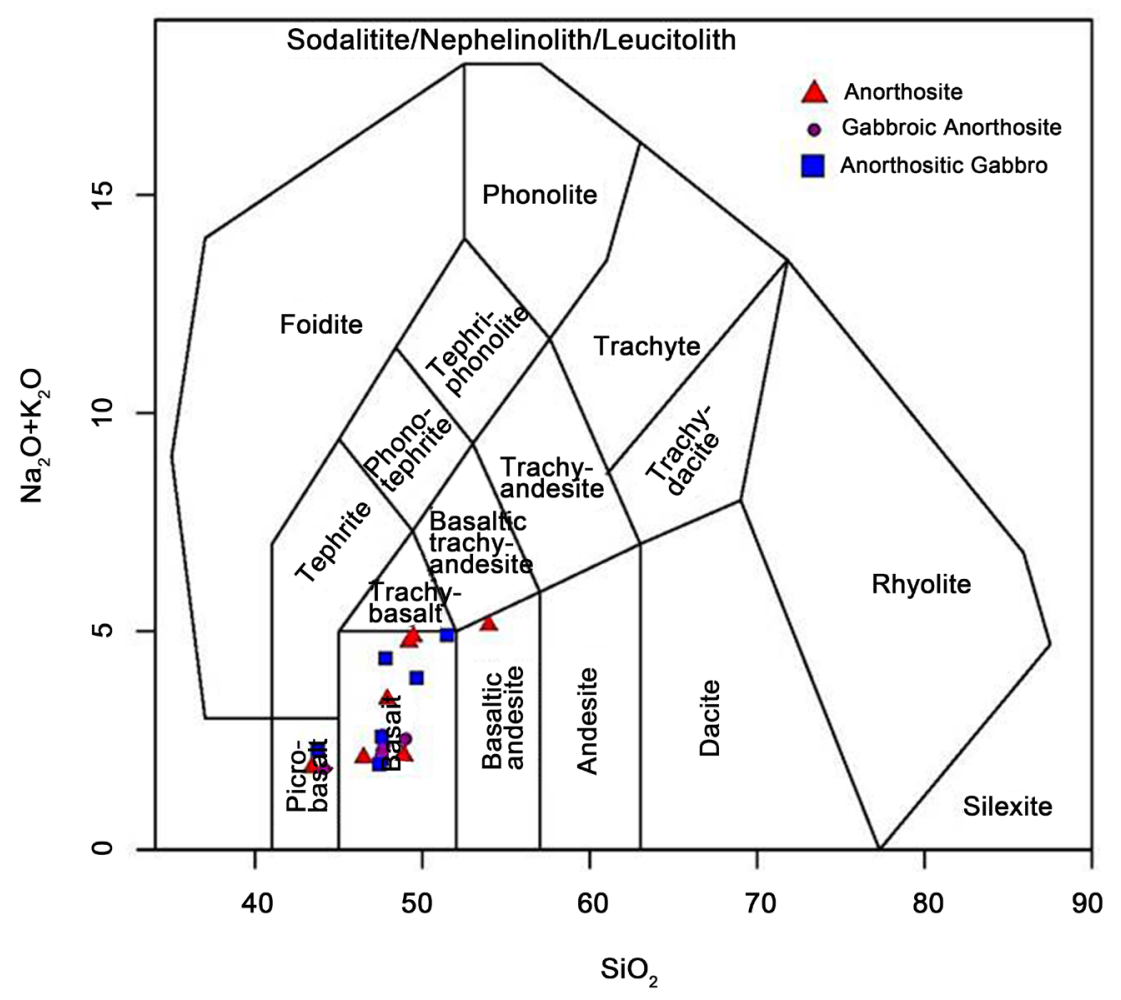

Figure 4. Alkali-silica classification diagram (TAS; wt\%), (Middlemost, 1994).

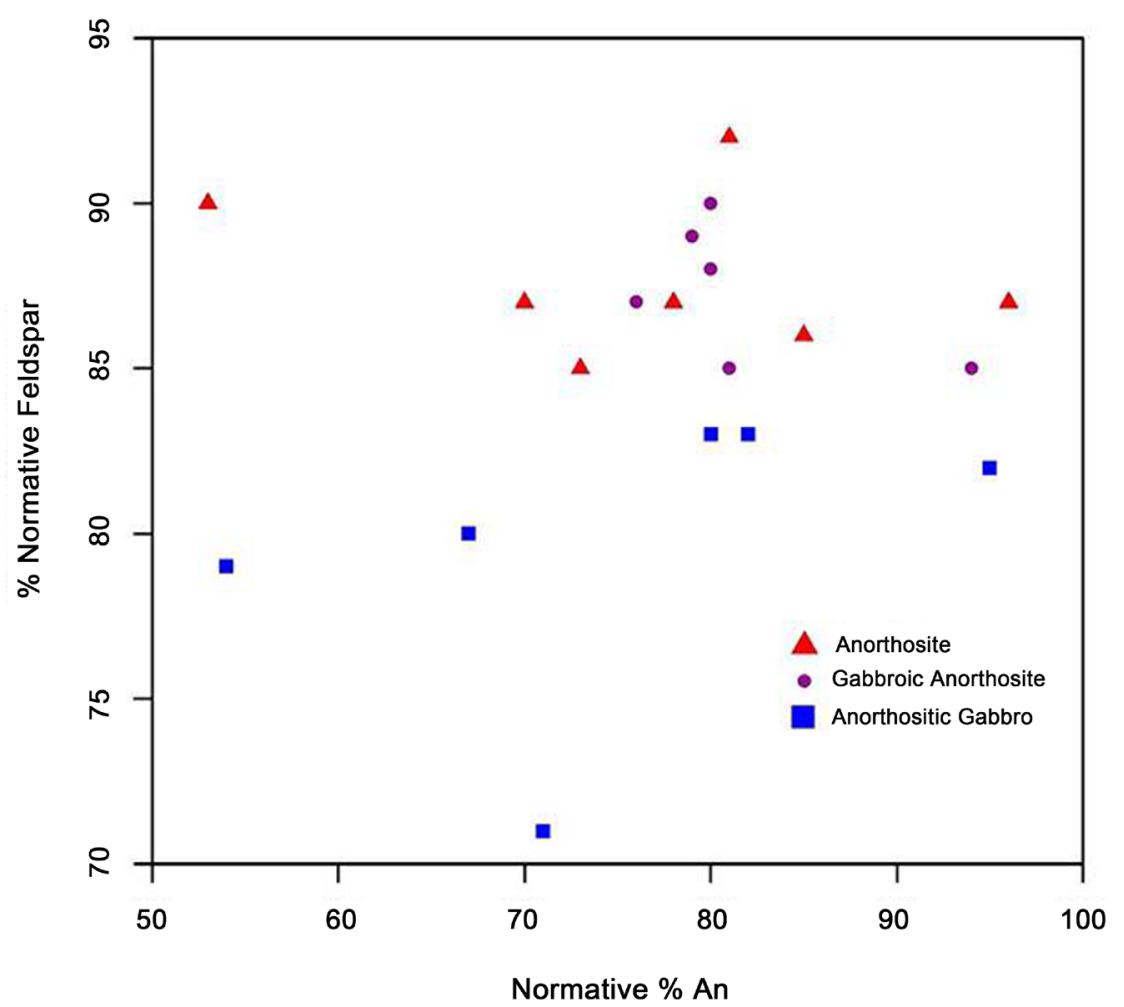

Figure 5. A plot of normative feldspar composition as $\%$ An or $100 \times A n /(A n+A b+O r)$ versus total amount of normative feldspar as $\sum(\mathrm{An}+\mathrm{Ab}+$ Or) (Dymek and Owens, 2001). 


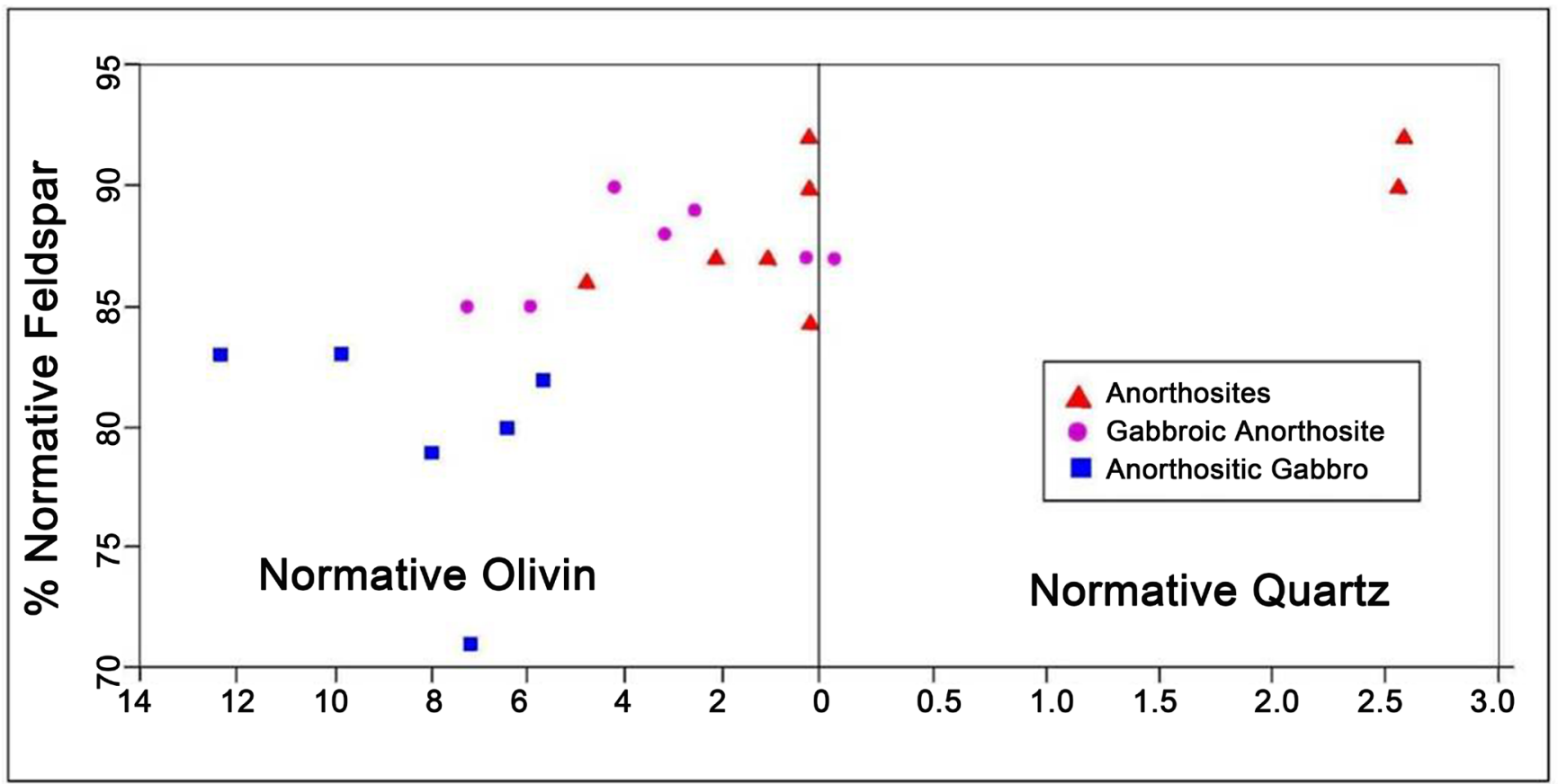

Figure 6. AS plot of silica saturation (represented as \% normative olivine or quartz) versus total amount of normative feldspar (Dymek and Owens, 2001).

abundance and compositions of cumulus plagioclases (and intercumulus mafic phases) particularly in the anorthositic rocks are not a good distinguished criteria and these chemical characteristics are broadly comparable to those of Archean anorthosites from amphibolite- and granulite-basis terrains, SW Greenland [42].

Gabbroic rocks of BAC contain higher contents of $\mathrm{MgO}(6.98-14.52 \mathrm{wt} \%)$ and $\mathrm{Fe}_{2}$ $\mathrm{O}_{3}\left(9.94 \%\right.$ - 11.92\%); and lower contents of $\mathrm{CaO}$ (10.23 - 10.42 wt\%) and $\mathrm{Al}_{2} \mathrm{O}_{3}$ (16.32 $19.23 \mathrm{wt} \%$ ) than those of anorthositic rocks (Table 2(b)). Therefore the gabbroic rocks show significant departure from anorthositic rocks (in figures). These geochemical disparities in gabbroic rocks are due to the presence of large quantity of cumulus pyroxenes in their mode. However, the contents of $\mathrm{SiO}_{2}$ (46.83 - $\left.47.2 \mathrm{wt} \%\right), \mathrm{Na}_{2} \mathrm{O}$ (0.98 $2.72 \mathrm{wt} \%), \mathrm{K}_{2} \mathrm{O}(0.05-0.18 \mathrm{wt} \%), \mathrm{TiO}_{2}(0.09-0.26 \mathrm{wt} \%)$ and $\mathrm{P}_{2} \mathrm{O}_{5}(0.01 \%)$ do not show significant variation from those of anorthositic rocks (Table 2(b)).

When the anorthosite rock samples are plotted in Harker diagram (Figure 7), they show gentle variation trends, where oxides of major elements $\left(\mathrm{Al}_{2} \mathrm{O}_{3}, \mathrm{CaO}, \mathrm{MgO}, \mathrm{TiO}_{2}\right.$ and $\mathrm{P}_{2} \mathrm{O}_{5}$ ) are negatively correlated with $\mathrm{SiO}_{2}$, only $\mathrm{Na}_{2} \mathrm{O}$ and $\mathrm{FeO}^{\mathrm{t}}$ despite some scatter exhibits positively correlated trend. Major element compositions are further illustrated in a series of variation diagrams (Figure 7). Clusters as well as spreads of points of major element data of anorthositic rocks in binary variation diagrams suggesting that these rocks are formed by the accumulation of different proportions of cumulus high calcic plagioclase and intercumulus minerals as hornblende ( \pm clinopyroxene and \pm $\mathrm{Fe}-\mathrm{Ti}$ oxides). The use of $\mathrm{MgO}$ as the index of variation is based on the assumption that the rocks were assembled as mixtures of plagioclase and mafic constituents. On the $\mathrm{MgO}-\mathrm{FeO}^{t}$ plot (Figure 8) the anorthosite samples are plotted at origin and gabbroic 

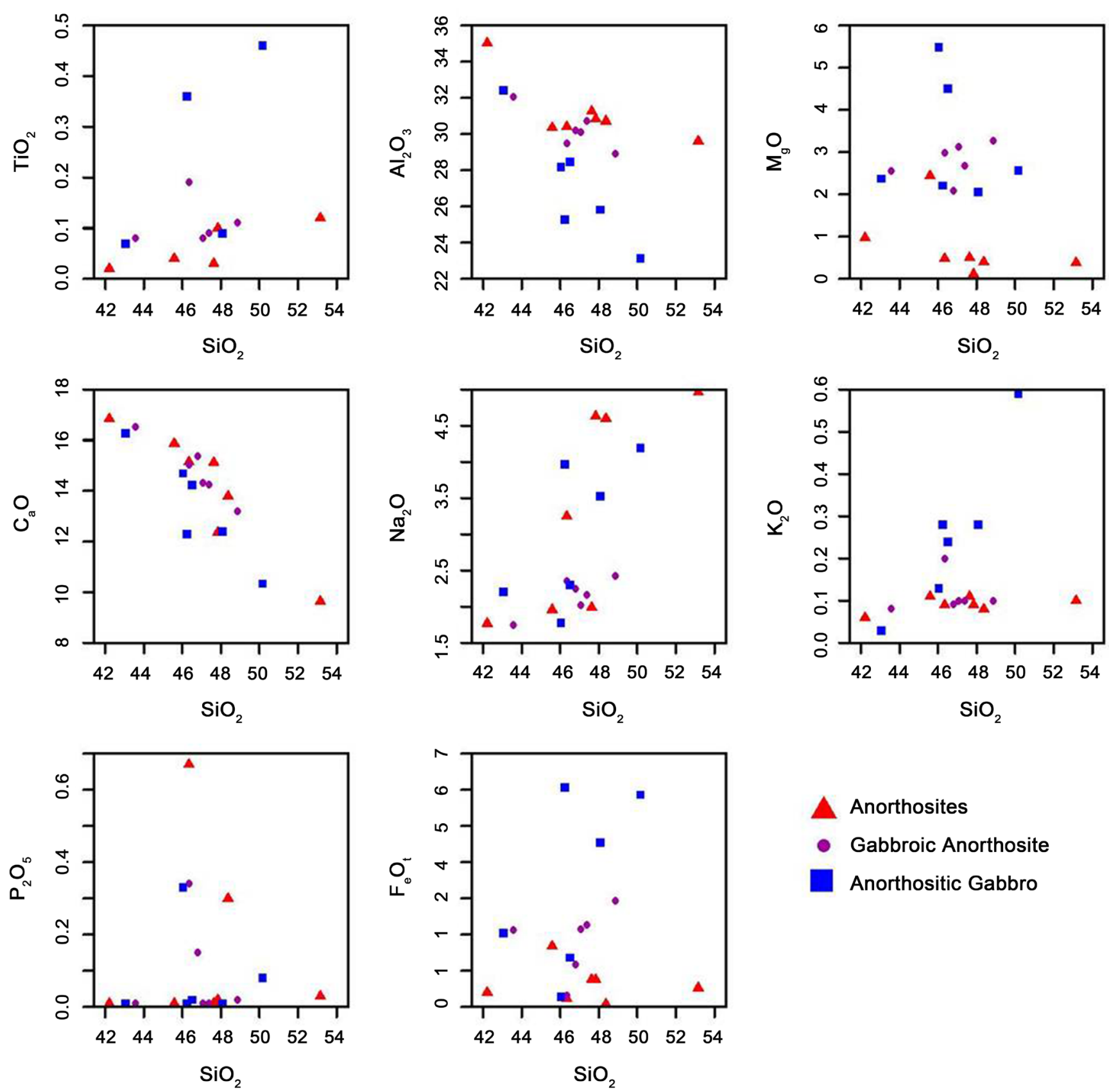

\section{- Anorthosites \\ - Gabbroic Anorthosite \\ Anorthositic Gabbro}

Figure 7. Plots of major elements (wt\%) vs. $\mathrm{SiO} 2$ (wt\%) for anorthosites, gabbroic anorthosites and anorthositicgabbros of the study area.

anorthosites show a positive intercept, which suggests that the primary plagioclase in these rocks was Fe-bearing, and/or, that a small amount of an essentially $\mathrm{Mg}$-free, and Fe-bearing phase (magnetite) was present in the protolith [42]. On the $\mathrm{CaO}$ and $\mathrm{Na}_{2} \mathrm{O}$ plots these rocks are formed as two groups as anorthosites and both gabbroic anorthosites/anorthositic gabbros. Low $\mathrm{MgO}$ with variable $\mathrm{CaO}$ and $\mathrm{Na}_{2} \mathrm{O}$, in anorthosites suggests variable plagioclase composition. In gabbroic anorthosite and anorthositic gabbro rocks an increase in $\mathrm{MgO}$ is accompanied by a general decrease in $\mathrm{CaO}$ and $\mathrm{Na}_{2} \mathrm{O}$, where as the data for $\mathrm{K}_{2} \mathrm{O}$ define a crude horizontal array. Such patterns indicate that 

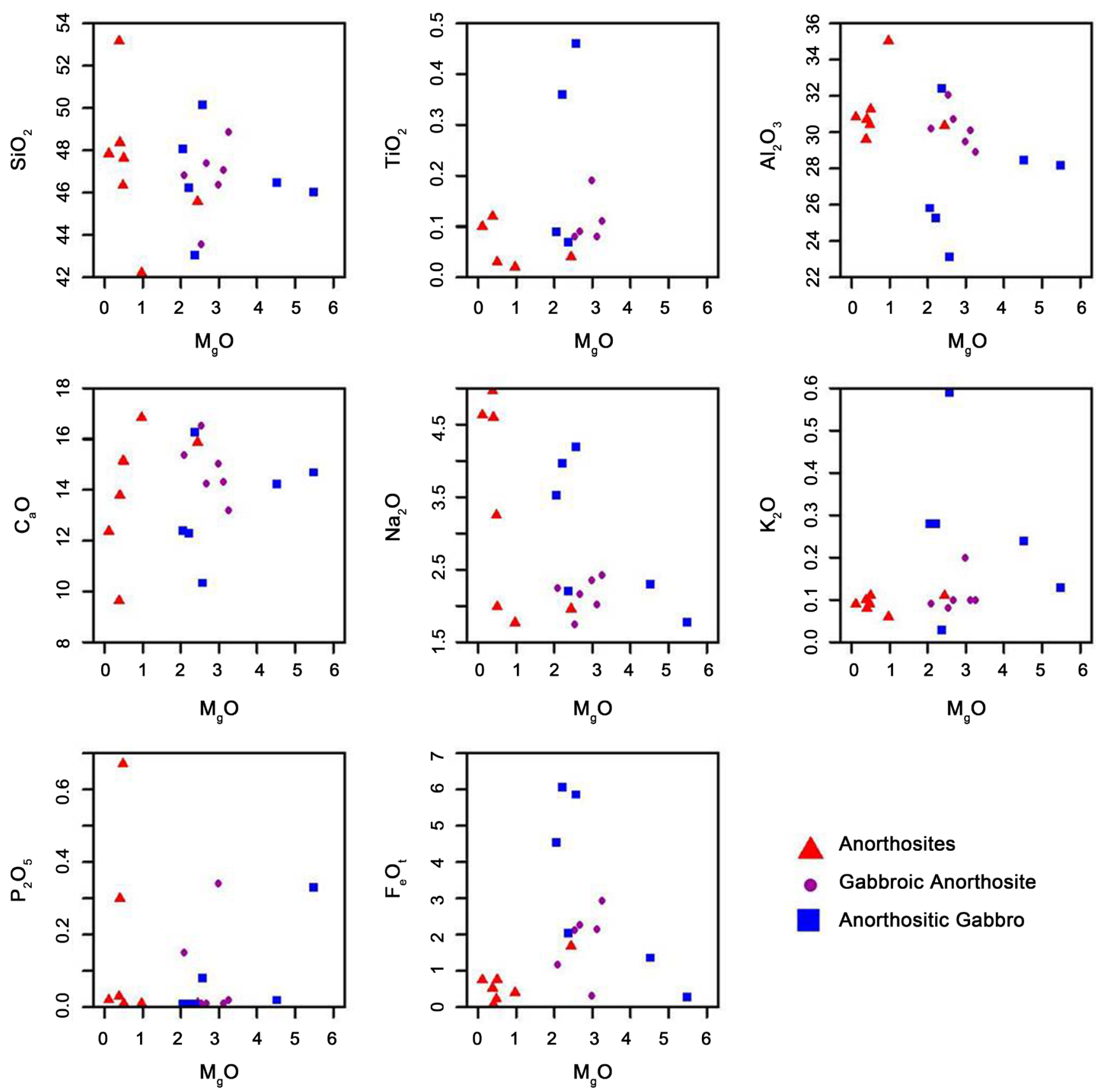

Figure 8. Weight \% oxide vs. $\mathrm{MgO}$ variation trends for anorthosite rocks of the study area.

the mafic components in these rocks contained $\mathrm{K}$, which in consistent with the possibility that the igneous precursors for these anorthosites contained hornblende.

The compositions of some preserved cumulus porphyroclasts as well as of the CIPW norms of the major-element analytical data of the anorthositic rocks show that plagioclase of average composition of $\mathrm{An}_{80}$ was on the liquids throughout much of the crystsallizational history of the BAC. The components $\mathrm{MgO}, \mathrm{Fe}_{2} \mathrm{O}_{3}, \mathrm{Al}_{2} \mathrm{O}_{3}, \mathrm{CaO}, \mathrm{K}_{2} \mathrm{O}$ and $\mathrm{Na}_{2} \mathrm{O}$ of parental magma may be estimated by using plagioclase fractionation trend. These 
trends are drawn through major element analytical data of the both anorthosite-and gabbroic-rocks shown in various binary fractionation diagrams. This geochemical variation in these rocks is reflected by polyphase deformation and metamorphism of amphibolite to lower granulite facies conditions.

The major element data of the rocks from BAC, and associated amphibolites are plotted on an AFM diagram (Figure 9) for geochemical comparison with those of Archean anorthosites occurring elsewhere [1] [23] since the rocks from the BAC are of cumulate in character. The anorthosites are expectedly lie close to the A corner in the A-F-M diagram, leucogabbros exhibit wide scatter in the middle of the calc-alkaline field and all these rocks are apparently confined to three widely separated zones which run nearly parallel to the F-M site suggesting considerable variation in the Fe-Mg ratio to a given total alkali content. The amphibolites are plotted in theoliietic field. The $\mathrm{MgO} / \mathrm{Na}_{2} \mathrm{O}$ ratio for $\mathrm{BAC}$ rocks is with 3.5 (i.e., 0.02 to 3.08). The $\mathrm{K}_{2} \mathrm{O} / \mathrm{CaO}$ ratios vary from 0.002 to 0.037 , thereby indicating little or no contamination from K-rich rocks. In this respect BAC compares with the Sittampudi, Karnataka and Archaean anorthosites, where the $\mathrm{K}_{2} \mathrm{O} / \mathrm{CaO}$ ratio ranges up to 0.04 .

Normative compositions of anorthosites are illustrated on a ternary An-Ab-Or (Figure 10). A comparison of these feldspar built compositions with the positions of the isotherms on the ternary feldspar solvus suggests a minimum temperature of crystallization $<750^{\circ} \mathrm{C}$, and crystallized at $>900^{\circ} \mathrm{C}$. Furthermore, the figure indicates that exsolution occurred at temperatures $<750^{\circ} \mathrm{C}$.

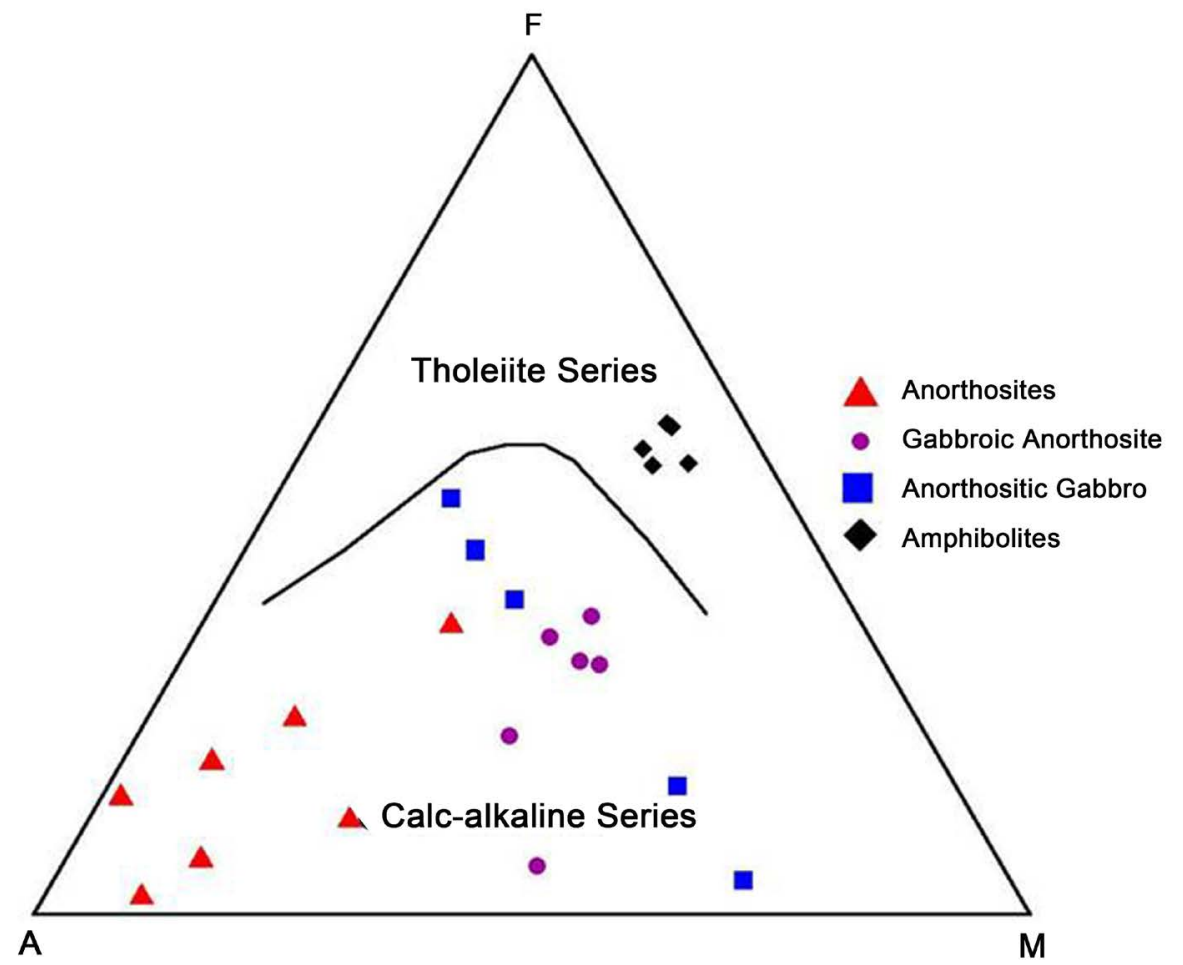

Figure 9. AFM triangular diagram, showing the demarcation between the tholeiitic and calc-alkaline divisions. 


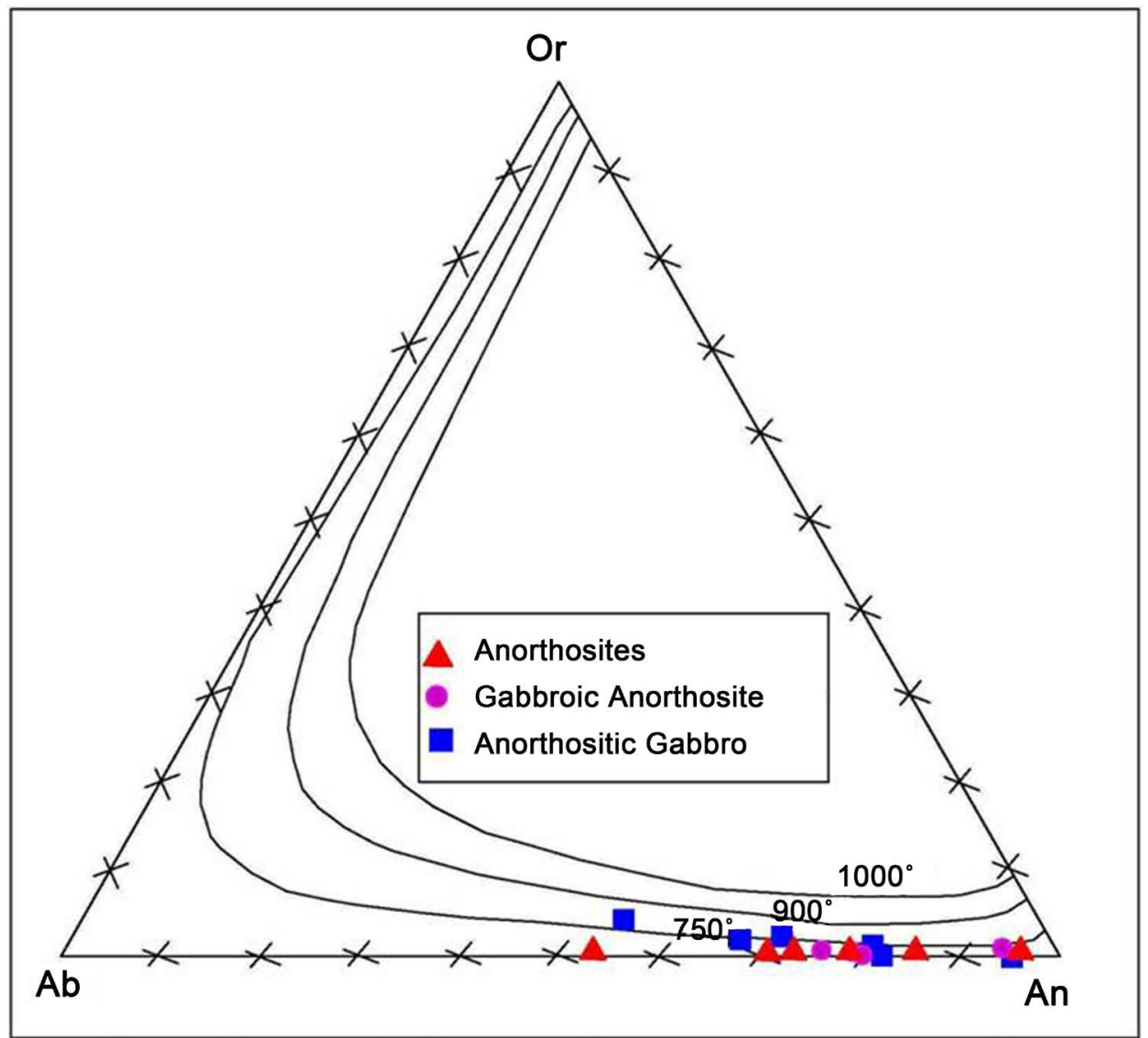

Figure 10. Ab-An-Or ternary plot of anorthosite whole rocks (Fulrman \& Lindsley, 1988).

\section{Discussion}

The formations of the study area show magmatic cross-bedding, graded bedding and cumulate structures. These field evidences indicate an undoubted igneous origin of the complex. This view is further corroborated by the twinning of plagioclase on Carlsbad and albite laws [43]. Layering is predominantly rhythmic type with alternating thin plagioclase-rich and hornblende rich layers. Layering involving different members of the complex i.e. anorthosite, gabbroic anorthosites, anorthositic gabbro, gabbros and ultramafic rock, is observed only at a few places of limited extent. The other layered complexes having cross bedding and graded bedding are skaergard intrusions and the Messina layered intrusion of Limpoo belt [23]. Opined that convection current was responsible for magmatic cross-bedding in skaergard. [35] considered the cross-stratification in chamber. [44] has discussed the role of the magmatic density currents in the cumulus processes in layered rocks.

Mose [45] stated that the magma will convict because it cools more rapidly at the top. It is therefore possible that crystals would form first at the top and those heavier than the liquid start settling downwards. The simplest convection pattern would be downward motion along the walls and inward convergence along the floor and outward dispersion along the roof. The convection, continuous or periodic, would influence the 
crystal deposition. Variation in the velocity of convection current will modify the rate between minerals of different settling velocities producing variations in the proportion of heavy and light minerals settling in the magma chamber. This would be a better working model to explain the rhythmic layering in the study area.

Batampudi complex has many characteristic features of the metamorphosed complexes. The plagioclase is strikingly rich in calcium with the anorthite molecular percentage ranging from $\mathrm{An}_{70}$ to $\mathrm{An}_{91}$ as in the case of most of the Archean anorthosites. Both orthopyroxene and clinopyroxene in different degrees of alteration are noticed. There are two types of hornblende viz; the pale green and olive green hornblende free from relict pyroxenes and blue green type with relict pyroxene and in some cases forming rims or coronas around pyroxenes could be of primary igneous origin. The whole rock chemistry reveals that the $\mathrm{BAC}$ is rich in $\mathrm{CaO}, \mathrm{Al}_{2} \mathrm{O}_{3}$ and poor in alkalies, in conformity with the Archaean layered anorthosites. The AFM diagram plots show a pure calc-alkalin and amphiblites show tholiietic differentiation trend. This is also in conformity with the views of [14] that the differentiation trends in metamorphosed layered complexes are believed to be similar and display a calc-alkaline trend.

\section{Conclusion}

The Bethampudi complex is essentially a leucogabbro (gabbroic anorthosite and anorthositic gabbro) with minor volumes of anorthoistes, gabbro, amphibolites, pegmatites and quartz veins occur as concordant or discordant bodies in the country rock. The layered leucogabbros show magmatic cross-bedding, graded bedding and cumulate structures. These field evidences indicate an undoubted igneous origin of the complex. The geochemical data suggest that the anothosites are of calc-alkaline and amphibolites have tholeiitic affinity. The presence of well-developed rhythmic layering indicates that fractional crystallization is generated by gravity settling of successively crystallizing cumulus minerals from a primitive basaltic magma, clinopyroxenite, gabbro, anorthositic gabbro and anorthosite, in this order to build up the study area complex, BAC. The parent magma, in general is basaltic with high alumina and low silica and alkalies. The plots on $\mathrm{SiO}_{2}$ and $\mathrm{MgO}$ versus alumina and alkalis indicate the tholeitic balsalt composition.

\section{References}

[1] Ashwal, L.D. (1993) Anorthosites. Springer, Berlin, 422. http://dx.doi.org/10.1007/978-3-642-77440-9

[2] Ashwal, L.D. (Ed.) (1988) Workshop on the Growth of Continental Crust. LIP Report 88-02, Lunar and Planetary Institute, Houston, $176 \mathrm{p}$.

[3] Weaver, B.L., Tarney, J. and Windley, B.F. (1981) Geochemistry and Pet-Rogenesis of the Fiskenaesset Anorthosite Complex, Southern West Greenland: Nature of the Parent Magma. Geochimica et Cosmochimica Acta, 45, 711-725. http://dx.doi.org/10.1016/0016-7037(81)90044-2

[4] Phinney, W.C., Morrison, D.A. and Maczuga, D.E. (1988) Anorthosites and Related Megacrystic Units in the Evolution of the Archean Crust. Journal of Petrology, 29, 1283-1323. 
http://dx.doi.org/10.1093/petrology/29.6.1283

[5] Dharma Rao, C.V., Santosh, M. and Wu, Y. (2011) Mesoproterozoic Ophiolite Mélange from the SE Periphery of Indian Plate: U-Pb Zircon Ages and Tectonic Implications. Gondwana Research, 19, 384-401. http://dx.doi.org/10.1016/j.gr.2010.06.007

[6] Dharma Rao, C.V., Windley, B.F. and Choudhary, A.K. (2011b) The Chimalpahad Anorthosite Complex and Associated Basaltic Amphibolites, Nellore Schist Belt, India: Magma chamber and Roof of a Proterozoic Island Arc. Journal of Asian Earth Sciences, 40, 10271043. http://dx.doi.org/10.1016/j.jseaes.2010.11.004

[7] Dharma Rao, C.V., Santosh, M. and Tang, Y. (2015) Re-Os Isotope Systematics of Archean Chromitites from the Chimalpahad Anorthosite Complex, South-East India: Implications for Mantle Extraction Processes. Ore Geology Reviews, 65, 274-282. http://dx.doi.org/10.1016/j.oregeorev.2014.09.033

[8] Arndt, N. (2013) The Formation of Massif Anorthosite: Petrology in Reverse. Geoscience Frontiers, 4, 195-198. http://dx.doi.org/10.1016/j.gsf.2012.08.002

[9] Mohan, M.R., Satyanarayanan, M. and Santosh, M. (2013) Neoarchean Suprasubduction Zone Arc Magmatism in Southern India: Geochemistry, Zircon U-Pb Geochronology and Hf Isotopes of the Sittampundi Anorthosite Complex. Gondwana Research, 23, 539-557. http://dx.doi.org/10.1016/j.gr.2012.04.004

[10] Ashwal, L.D. and Myers, J.S. (1994) Archean Anorthosites. In: Condie, K.C., Ed., Archean Crustal Evolution, Elsevier, Amsterdam, 315-355. http://dx.doi.org/10.1016/S0166-2635(08)70226-3

[11] Narsimha Reddy, M. and Leelanandam, C. (2004) Magmatic and Tectonic Structures from the Chimalpahad Layered Complex, Andhra Pradesh, India. Gondwana Research, 7, 887896. http://dx.doi.org/10.1016/S1342-937X(05)71072-8

[12] Dharma Rao, C.V. and Reddy, U.V.B. (2009) Petrological and Geochemical Characterization of Proterozoic Ophiolitic Mélange, Nellore-Khammam Schist Belt, SE India. Journal of Asian Earth Sciences, 36, 261-276. http://dx.doi.org/10.1016/j.jseaes.2009.05.009

[13] Dharma Rao, C.V. and Santosh, M. (2011) Continental Arc Magmatism in a Mesoproterozoic Convergent Margin: Petrological and Geochemical Constraints from the Magmatic Suite of Kondapalle along the Eastern Margin of the Indian Plate. Tectonophysics, 510, 151-171. http://dx.doi.org/10.1016/j.tecto.2011.06.025

[14] Windley, B.F. (1973) Achaean Anorthosites: A Review with the Fiskenaesset Complex, West Greenland, as a Model for Interpretation. Special Publication Geological Society of South Africa, 3, 319-332.

[15] Leelanandam, C. (1987) Proterozoic Anorthosite Massifs: An Overview. Indian Journal of Geology, 59, 179-194.

[16] Harpum, J.R. (1957) Intervention in Boulanger, J. Les anorthosites de Madagascar. Communication for Technology Co-operation in Africa South of the Sahara, Conference de Tananarive, Premier, 2, 71-92.

[17] Windley, B.F. (1969) Anorthosites of Southern West Greenland Mem. American Association of Petroleum Geologists, 12, 899-915.

[18] Windley, B.F. (1969) Evolution of the Early Precambrian Basement Complex of Southern West Greeenland. Geological Association of Canada Special Paper 5, 155-161.

[19] Windley, B.F. (1970) Primary Quatrz Ferro-Dolerite/Garnet Amphibolites Dykes in the Sukkertoppen Region of West Greenland. In: Newall, G. and Rast, N., Eds., Mechanisms of Igneous Intrusions, Geological Journal Special Issue No. 2, 79-92. 
[20] Garson, M.S. and Livingstone, A. (1973) Is the South Harris Complex in North Scotland a Precambrian Overthrust Slice of Oceanic Crust and Island Arc? Nature Physical Science, 243, 74-76. http://dx.doi.org/10.1038/physci243074a0

[21] Windley, B.F. and Smith, J.V. (1976) Archean High Grade Complex and Modern Continental Margin. Nature, 260, 671-675. http://dx.doi.org/10.1038/260671a0

[22] Sleep, N.H. and Windley, B.F. (1982) Archean Plate Tectonics: Constraints and Inferences. Journal of Geology, 90, 363-379. http://dx.doi.org/10.1086/628691

[23] Barton Jr., J.M., Fripp, R.E.P., Horrocks, P. and Mclean, N. (1979) The Geology Age and Tectonics Setting of the Messina Layered Intrusion, Limpopo Mobile Belt, Southern Africa. American Journal of Science, 279, 1108-1134. http://dx.doi.org/10.2475/ajs.279.10.1108

[24] Simmons, E.C., Hanson, G.N. and Lumbers, S.B. (1980) Geochemistry of the Shawmere Anorthosites Complex, Kapuskasing Strctual Zone, Ontario. Precambrian Research, 11, 4371. http://dx.doi.org/10.1016/0301-9268(80)90080-7

[25] Ashwal, L.D., Morrison, D.A., Phinney, W.C. and Wood, J. (1983) Origin of Archean Anorthosites: Evidence from the Bad Vermilion Lake Anorthosite Complex, Ontario. Contributions to Mineralogy and Petrology, 82, 259-273. http://dx.doi.org/10.1007/BF01166620

[26] Bose Mihir, K. (2007) Chimalpahad Anorthosite Complex-An Exile from the Eastern Ghats Belt of the India Shield. Igneous Petrology: 21st Century Perspective. Jyotisankar and Bhattacharyya, Department of Geology, University of Calcutta, India.

[27] Leelanandam, C. and Narsimha Reddy, M. (1983) Plagioclase Feldspars and Hornblende from the Chimalpahad Complex, Andhra Pradesh, India. Neues Jahrbuch für Mineralogie Abhandlungen, 148, 200-222.

[28] Leelanandam, C. and Narsimha Reddy, M.N. (1985) Petrology of the Chimalpahad Anorthosite Complex, Andhra Pradesh, India. Neues Jahrbuch für Mineralogie Abhandlungen, 153, 91-119.

[29] Myers, J.S. (1985) Stratigraphy and Structure of the Fiskenaesset Complex, Southern West Greenland. Bull Greenlands Geol Unders 150.

[30] Subramaniam, A.P. (1956) Mineralogy and Petrology of the Sittampundi Complex, Salem District, Madras State, India. Geological Society of America Bulletin, 67, 317-390. http://dx.doi.org/10.1130/0016-7606(1956)67[317:MAPOTS]2.0.CO;2

[31] Janardhanan, A.S. and Leake, B.E. (1975) The Origin of the Meta-Anorthositic Gabbros and Garnetiferous Granulites of the Sittampundi Complex, Madras, India. Journal of the Geological Society of India, 16, 391-408

[32] Windley, B.F. and Selvan, T.A. (1975) Anorthosites and Associated Rocks of Tamil Nadu, Southern India. Journal of the Geological Society of India, 16, 209-215.

[33] Hor, A.K., Hutt, D.K., Wakefiled, J. and Windley, B.F. (1975) Petrochemistry and Mineralogy of Early Precambrian Anorthositic Rocks of the Limpopo Belt, Southern Africa. Lithos, 8, 297-310. http://dx.doi.org/10.1016/0024-4937(75)90013-4

[34] St-Onge, M.R. and Ijewliw, O.J. (1996) Mineral Corona Formation during High-Pretrogression of Granulitic Rocks, Ungava Orogen, Canada. Journal of Petrology, 37, 553-582. http://dx.doi.org/10.1093/petrology/37.3.553

[35] Ramamohana Rao, T.B.V. and Satyanarayana, R. (1986) Stratification and Cross-Stratification in the Layered Anorthosite of Chimalpahad, Khammam District, Andhra Pradesh, India. Journal of Geological Society of India, 28, 51-53.

[36] Dasgupta, S. and Sengupta, P. (2003) Indo-Antarctic Correlation: A Perspective from the Eastern Ghats Granulite Belt, India. In: Yoshida, M., Windley, B.F. and Dasgupta, S., Eds., 
Proterozoic East Gondwana: Supercontinent Assembly and Breakup, Geological Society, London, Special Publications 206, 131-143. http://dx.doi.org/10.1144/gsl.sp.2003.206.01.08

[37] Narsimha Reddy, M. and Leelanandam, C. (1999) Textural Characteristics and Mineral Chemistry of the Gabbroic rocks from the Chimalpahad Layered Complex, Andhra Pradesh, India. International Symposium on Charnockite and Granulite Facies Rocks, Tamil Nadu, 29 August-2 September 1999, 63-76.

[38] Paterson, D. and Newton, R.C. (1989) Reversed Experimental Calibration of the GarnetClinopyroxene Fe-Mg Exchange Thermometer. Contributions to Mineralogy and Petrology, 101, 87-103. http://dx.doi.org/10.1007/BF00387203

[39] Tracy, R.J. and McLellan, E.L. (1985) A Natural Example of the Kinetic Controls of Compositional and Textural Equilibration. In: Thompson, A.B. and Rubie, D.C., Eds., Metamorphic Reactions-Kinetics, Textures and Deformation, Springer, Berlin, 118-137. http://dx.doi.org/10.1007/978-1-4612-5066-1_5

[40] Myers, J.S. and Platt, R.G. (1977) Mineral Chemistry of Layered Archaean Anorthosite at Majorqap Qava, Near Fiskenaesset, Southwest.

[41] Bhaskar Rao, Y.J., Chetty, T.R.K., Jamardhan, A.S. and Gopalan, K. (1996) Sm-Nd and Rb-Sr Ages and P-T History of the Archean Sittampudi and Bhavani Layeremeta-Anorthosite Complexs in Cauvery Shear Zone, South India: Evidence for Neoproterozoic Reworking of Archean Crust. Contributions to Mineralogy and Petrology, 125, 237-250. http://dx.doi.org/10.1007/s004100050219

[42] Dymek, R.F. and Owens, B.E. (2001), Petrogenesis of the Labrieville Alkalic Anorthosite Massif, Grenville Province Quebec. Journal of Petrology, 42, 1519-1546. http://dx.doi.org/10.1093/petrology/42.8.1519

[43] Gorai, M. (1951) Petrological Studies on Plagioclase Twins. American Mineralogist, 36, 884-901.

[44] Irvine, T.N. (1980) Infiltration Metasomatism Accumulate Growth and Double-Diffusive Fractional Crystallization in the Muskox Intrusion and Other Layered Intrusions. In: Hargraves, R.B., Physics of Magmatic Processes, Princeton University Press, Preinceton, 325-383.

[45] Mose, S.A. (1980) Basalts and Phase Daigrams. Springer, New York, 493 p.

[46] Middlemost, A.K. (1994) Naming Materials in the Magma/Igneous Rock System. EarthScience Reviews, 37, 215-224. http://dx.doi.org/10.1016/0012-8252(94)90029-9 
Submit or recommend next manuscript to SCIRP and we will provide best service for you:

Accepting pre-submission inquiries through Email, Facebook, LinkedIn, Twitter, etc. A wide selection of journals (inclusive of 9 subjects, more than 200 journals)

Providing 24-hour high-quality service

User-friendly online submission system

Fair and swift peer-review system

Efficient typesetting and proofreading procedure

Display of the result of downloads and visits, as well as the number of cited articles

Maximum dissemination of your research work

Submit your manuscript at: http://papersubmission.scirp.org/

Or contact ojg@scirp.org 